\title{
Cyclic Nucleotide Phosphodiesterase Activities of the Human Liver: Comparison between Control and Reye's Syndrome Samples
}

\author{
ELLEN S. KANG ${ }^{(39)}$ \\ Department of Pediatrics and Department of Medicine, Division of Gastroenterology, University of Tennessee Center \\ for the Health Sciencies; and St. Jude Children's Research Hospital, Memphis, Tennessee, USA
}

\section{Summary}

The specific activity and kinetic constants of the four forms of cyclic nucleotide phosphodiesterase (PDE) activities of liver obtained at autopsy from patients with and without Reye's syndrome have been analyzed and compared. Assays were conducted on supernatants of $30,000 \times g$ spun homogenates after dialysis to remove endogenously accumulated substrate.

$K_{m}$ values were derived by the double reciprocal plot method. $A$ higher mean value for the low affinity cAMP activity is found in Reye's subjects $\left(11.36 \pm 7.33 \times 10^{-4} \mathrm{M}\right.$ compared to $3.6 \pm 1.73$ $\times 10^{-4} \mathrm{M}$ for controls). Values for the other forms are similar between groups. Values for controls are: $4.03 \pm 1.8 \times 10^{-6} \mathrm{M}$ for the high affinity cAMP PDE activity and $2.57 \pm 0.27 \times 10^{-4} \mathrm{M}$ and $8.28 \pm 5.74 \times 10^{-6} \mathrm{M}$ for the low plus high affinity cGMP PDE activities. Differences in $V_{\max }$ values are not statistically significant.

At 10 and $500 \mu M$ cAMP concentrations, infants exhibit the highest specific activities. When all subjects in each group are included in calculation of the mean specific activity, no difference of significance is apparent. If all infant values are excluded from both groups, the mean specific activity of the high $K_{m}$ or low affinity cAMP PDE obtained for Reye's subjects is significantly higher than for control subjects $(4.18 \pm 2.17 \mathrm{nmol} / \mathrm{mg} / \mathrm{min}$ compared to $1.52 \pm 0.93$ ). Such differences are not observed for the low $K_{m}$ or high affinity $c A M P P D E$ or for the high and low affinity cGMP PDE enzymes.

In supernatant fractions from both groups, the presence of $10^{-6}$ $M$ cGMP enhanced the cAMP hydrolyzing capacity. Higher concentrations of cGMP are inhibitory for both forms of cAMP PDE.

\section{Speculation}

These observations raise the distinct possibility that children who develop Reye's syndrome may exhibit an altered responsiveness to the polypeptide hormones which utilize the second messenger system to produce their intracellular effects.

The concentration of cAMP in plasma has been reported to be elevated in Reye's syndrome (16). Because this cyclic nucleotide originates within cells, this finding suggests that the intracellular concentration of this nucleotide must have been increased earlier in the course of the disease.

High concentrations of cAMP in specific target tissues can result in the excessive release of substrates for gluconeogenesis, i.e., alanine from muscle (10); free fatty acids and glycerol from adipose tissue (5). Among the abnormalities which characterize Reye's syndrome are hyperalaninemia $(15,17)$, increased concentrations of free fatty acids (4), and glycerol (16). Thus, it appears that some of the disturbances seen in this disease not only parallel but may be secondary to the excessive accumulation of cAMP in specific tissues.

In an earlier publication, we reported an increase in basal activity of adenylate cyclase in fat tissues from Reye's subjects obtained at postmortem (16). However, liver and brain tissue activities were comparable to controls. The activity of the degrading enzyme, PDE, was kinetically analyzed in brain without demonstrable difference between the two groups. The specific activity of PDE in adipose tissue and liver was examined only at 2 mM cAMP concentration. No difference was observed (16).

We have now extended our study of PDE in the liver to include concentrations of cAMP substantially lower and more physiologic than $2 \mathrm{mM}$. In this report we characterize PDE activity of human liver obtained from Reye's syndrome subjects at the time of autopsy and from patients who died from a variety of other causes. We note the existence of several kinetic forms including their kinetic constants and the effect of the other naturally occurring cyclic nucleotide, cGMP, on the hydrolysis of cAMP. Furthermore, significant differences in the high $K_{m}$ cAMP PDE activity are demonstrated between control subjects and children who succumb to Reye's syndrome.

\section{MATERIALS AND METHODS}

\section{CLINICAL MATERIALS}

Tissues for enzyme studies were collected at autopsy and kept frozen at $-80^{\circ}$ until analysis. Pertinent laboratory and clinical features of these subjects are present in Table 1 .

PDE assays were performed on representative sections of liver.

All tissues were obtained with the informed consent of the responsible next of kin.

Phosphodiesterase activity was assayed in the supernatant and particulate fractions of liver after homogenization in 3 vol glassdistilled water, rapid freeze-thawing three times, centrifugation at $30,000 \times g\left(0-4^{\circ}\right)$ for $30 \mathrm{~min}$ and dialyzing overnight at $4^{\circ}$ in Tris buffer, $20 \mathrm{mM}, \mathrm{pH}$ 7.4. Amounts of protein used over a 4-min period of incubation at $34-36^{\circ}$ were $50-100 \mu \mathrm{g}$ in $100 \mu \mathrm{l}$ total volume in $40 \mathrm{mM}$ Tris- $\mathrm{HCl}, \mathrm{pH} 7.4 . \mathrm{Mn}^{++}$was used as the divalent cation at a final concentration of $2 \mathrm{mM}$ for liver. The two-step isotopic method of Thompson and Appleman was used (35). Substrate concentrations varied over a range of $2 \times 10^{-3}-10^{-8} \mathrm{M}$. Percentage conversion of labeled substrate to $5^{\prime}$-AMP was determined in an aliquot of the supernatant after resin precipitation in Bray's solution by scintillation spectrophotometry (This method has been reported to underestimate PDE activity (21). Since all of our assays were performed identically, results relative to each other are clearly valid.)

[8- $\left.{ }^{3} \mathrm{H}\right] \mathrm{cAMP}$ was purchased from Schwarz-Mann and $\left[G^{-}{ }^{3} \mathrm{H}\right]$ cGMP was obtained from New England Nuclear. Isotopes were further purified by chromatography on thin layer plates of cellu- 
Table 1. Pertinent data of autopsied subjects ${ }^{1}$

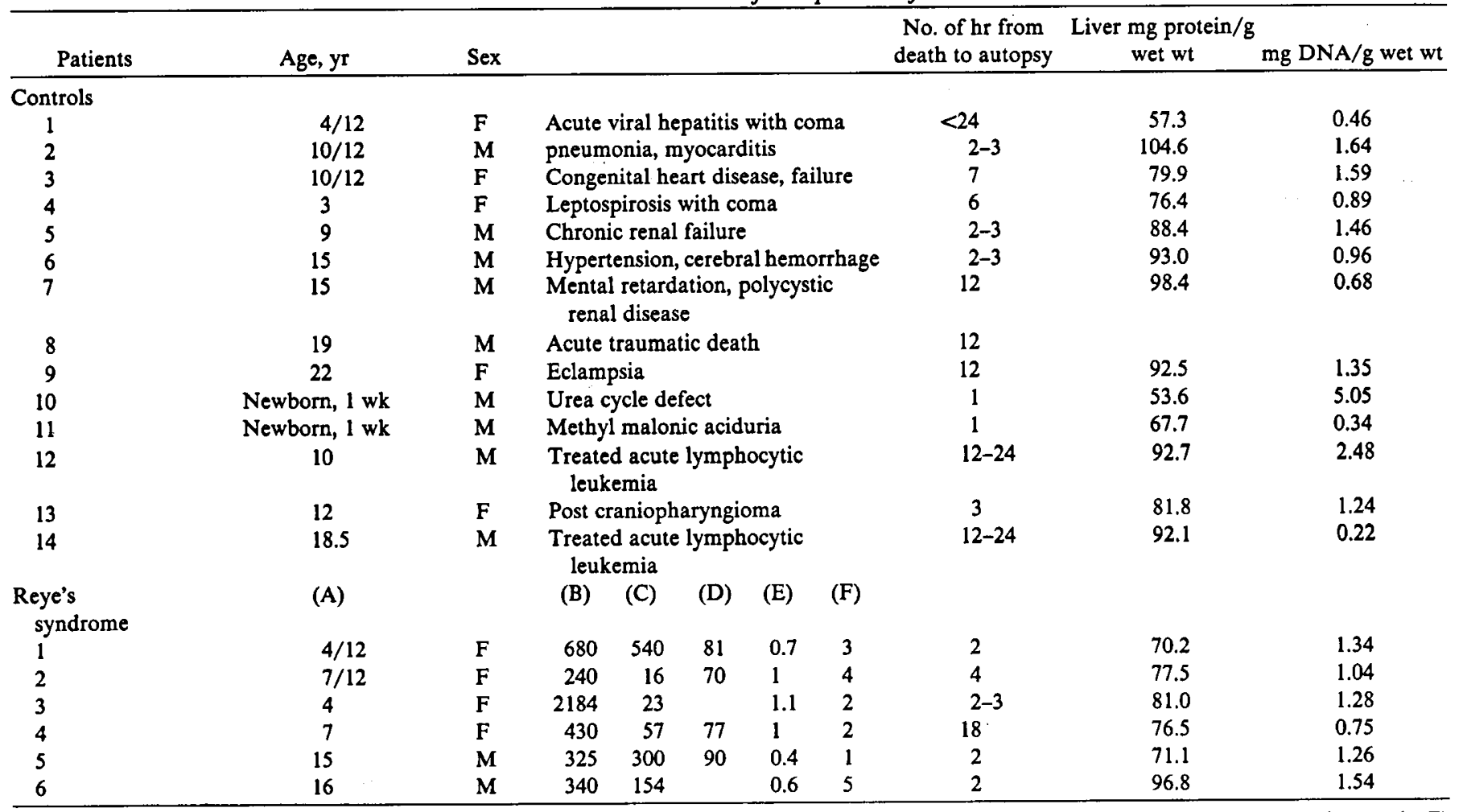

${ }^{1}$ (A) all with clear cerebrospinal fluid; (B) SGOT in units; (C) plasma glucose (milligrams per $100 \mathrm{ml}$ ); (D) prothrombin, percent of control; (E) plasma bilirubin (milligrams per $100 \mathrm{ml}$ ); (F) number of days from onset of encephalopathy to death.

Table 2. Effect of storage on liver PDE activity (nanomoles hydrolyzed per $\mathrm{mg}$ protein per $\mathrm{min})^{1}$

\begin{tabular}{lcc}
\hline & & $\begin{array}{c}\text { Activity after 6-mo inter- } \\
\text { val }\end{array}$ \\
\hline Control 3 & Initial activity & 3.53 \\
Control 4 & 3.92 & 1.57 \\
Reye's 3 & 2.13 & 4.07 \\
\hline
\end{tabular}

${ }^{1}$ cAMP $200 \mu \mathrm{M}, 37^{\circ}$.

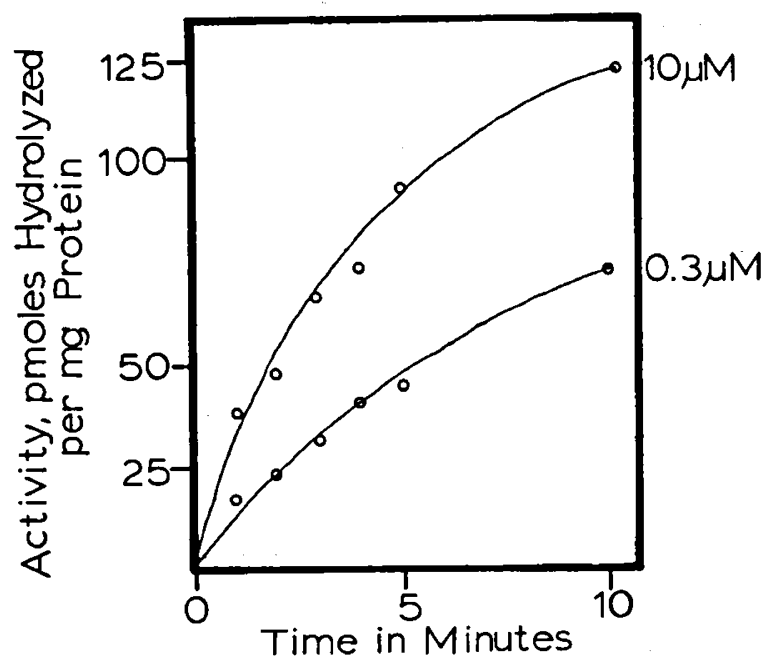

Fig. 1. Effect of time on cAMP PDE activity of liver supernatant at micromolar concentrations. Incubated for varying times in $100 \mu 140 \mathrm{mM}$ Tris- $\mathrm{HCl}$, pH 7.4, containing $2 \mathrm{mM} \mathrm{Mn}^{++}, 10$ or $0.3 \mu \mathrm{M}$ cAMP $\left(\left[8{ }^{3} \mathrm{H}\right]\right.$ cAMP, $0.02 \mathrm{uCi})$, and $68 \mu \mathrm{g}$ protein at $34 \div 36^{\circ}$, Reaction terminated by boiling 2-3 min. Product, tritrated 5 '-AMP converted to $\left[{ }^{3} \mathrm{H}\right]$ adenosine using Crotalus atrox (35) which was separated by ion-exchange resin. lose in 2-propanol, ammonia, water (7:1:1) before use (33). All other chemicals were of reagent grade.

Protein was determined by the method of Lowry with bovine serum albumin as a standard (22). DNA was measured by the diphenylamine method of Burton (6).

Changes in total PDE activity due to variation in duration of storage before analysis was negligible for a 6-month interval as seen by the results of repeat analysis on three individual specimen presented in Table 2. Similar results were observed on repeat analysis of cAMP PDE activity at lower substrate concentrations.

To determine a common basis for comparison of enzyme activity from subjects of wide age differences, changes in protein and DNA content of liver were determined in control liver samples. Age effects on DNA and protein content of liver are apparent. Results fluctuate probably due to individual subject variations (see Table 1). The least variable parameter appears to be protein. Therefore, PDE activity is computed based on this factor.

\section{RESULTS}

\section{CAMP PDE ACTIVITY}

PDE activity in the supernatant fraction of $30,000 \times g$ spun liver homogenates is time, concentration, and protein dependent (see Figs. 1-4). Double reciprocal plots demonstrate anomalous kinetics suggestive of at least two types of activity, one exhibiting low and the other high affinity for cAMP (Fig. 4).

Nonlinear plots for the phosphodiesterases have been found in a wide range of tissues from diverse animal sources (1). This phenomenon has been attributed to the existence of multiple enzymes with varying affinities for both nucleotides (32) or to the possibility of negative cooperativity of allosteric enzymes in which binding at high affinity sites induces a conformational change in the enzyme leading to a lower affinity at a second site $(8,20,32)$.

Comparison of the kinetic constants between Reye's and control subjects reveals a significant difference between the $\mathrm{K}_{\mathrm{m}}$ values of 
the low affinity enzyme activity (see Table 3 ). Mean values obtained were $3.6 \pm 1.73 \times 10^{-4} \mathrm{M}$ for controls and $11.36 \pm 7.73$ $\times 10^{-4} \mathrm{M}$ for Reye's samples $\left(\mathrm{t}_{12}=2.7838 ; P\right.$ between 0.025 and 0.010 ).

Kinetic constants obtained from the analysis of particulate fractions gave high affinity values similar to those observed in supernatant fractions.

At 10 and $500 \mu \mathrm{M}$ cAMP concentrations, higher PDE activities are exhibited by infants (see Fig. 5 and 6 ). If this higher activity in infants is not taken into consideration, mean values for Reye's and control samples are comparable. If the contribution of high values by infants to both control and Reye's groups is removed, a difference of significance in the specific activity of PDE is seen at the higher substrate concentration. A mean value of $4.18 \pm 2.17$ $\mathrm{nmol} / \mathrm{ml} / \mathrm{min}$ is obtained for Reye's samples whereas the value is $1.52 \pm 0.93$ for controls $\left(t_{8}=2.7134, P\right.$ between 0.050 and 0.025$)$. Despite differences in methodology and the rather long incubation

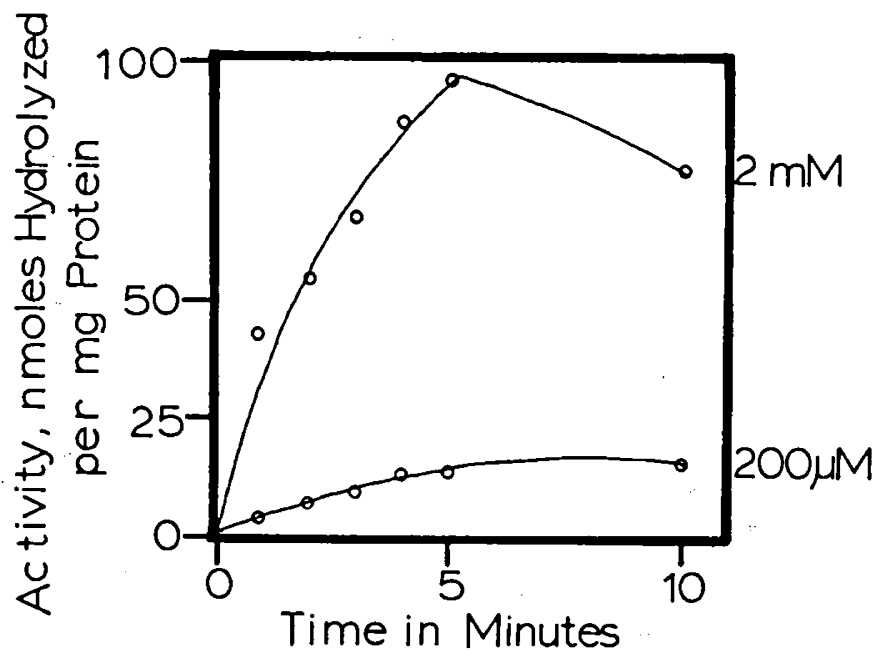

Fig. 2. Effect of time on cAMP PDE activity of liver supernatant at millimolar concentrations. Incubation in $100 \mu \mathrm{l}$ total volume, $40 \mathrm{mM}$ Tris$\mathrm{HCl}, \mathrm{pH} 7.4: \mathrm{Mn}^{++} 2 \mathrm{mM} ; 200 \mu \mathrm{M}$ or $2 \mathrm{mM}$ cAMP $\left(\left[8{ }^{3} \mathrm{H}\right] \mathrm{cAMP}, 0.02\right.$ $\mu \mathrm{Ci})$; and $68 \mu \mathrm{g}$ protein at $34-36^{\circ}$. The two-step procedure of Thompson and Appleman (35) was used.

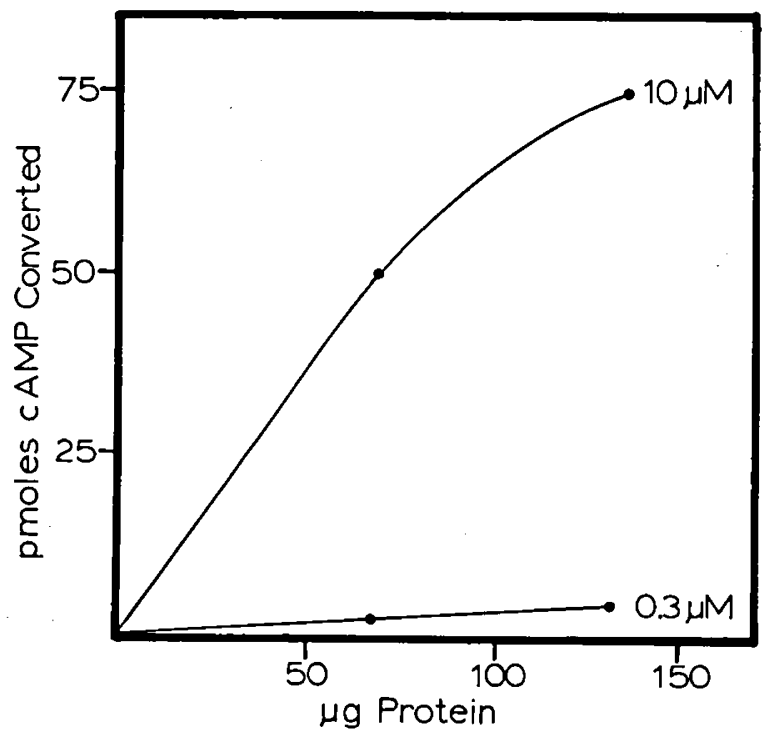

Fig. 3. Effect of increasing protein on CAMP PDE activity at micromolar concentrations. Total volume $100 \mu \mathrm{l}, 40 \mathrm{mM}$ Tris- $\mathrm{HCl}, \mathrm{pH} 7.4 ; \mathrm{Mn}^{++} 2$ $\mathrm{mM}$; cAMP as indicated $(0.02 \mathrm{uCi}), 34-36^{\circ}$ according to the method of Thompson and Appleman (35).

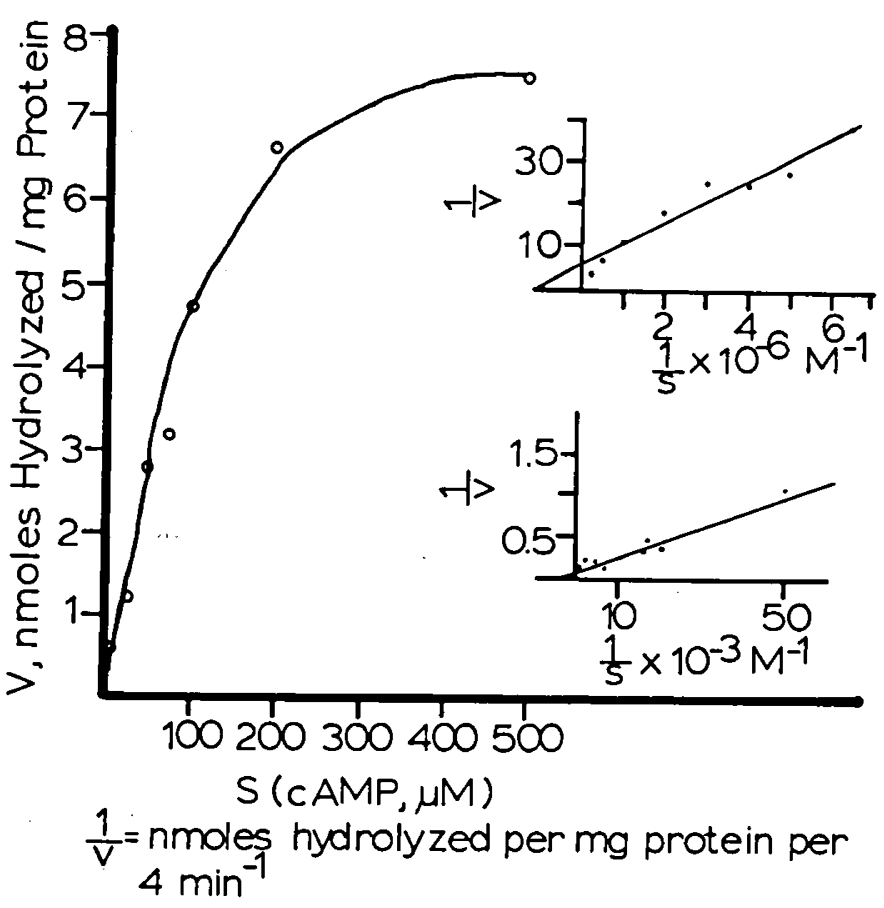

Fig. 4. Initial velocity at varying cAMP concentrations and double reciprocal plots.

time (30 $\mathrm{min}$ ) used by Menahan et al. (26), specific activities of liver specimen from two normal adults were comparable to the activities found in our series $(3.62$ and $1.50 \mathrm{nmol} / \mathrm{mg} / \mathrm{min}$ ).

cGMP affects the hydrolysis of cAMP in a variety of mamalian tissues (2). In the liver of both Reye's and control subjects, the addition of $10^{-6} \mathrm{M}$ cGMP enhanced the ability of PDE to hydrolyze cAMP over a wide range of concentrations. The increase in activity ranged from $50-250 \%$. Higher concentrations of cGMP progressively inhibited cAMP hydrolysis. In the presence of millimolar concentrations of cGMP the activity of CAMP PDE was reduced by $40-87 \%$ (see Fig. 7). cGMP increased the $K_{m}$ and $V_{\max }$ values of the high affinity (low $K_{m}$ ) cAMP PDE activity and had a variable effect on the constants of the low affinity high $\mathrm{K}_{m}$ cAMP PDE (see Table 4). No significant difference in these effects was noted between Reye's and control samples.

\section{cGMP PDE ACTIVITY}

Liver supernatant fractions demonstrated cGMP hydrolizing capability which is concentration, protein, and time dependent also. No significant age effect is noted in the small groups studied and Reye's and control activities are similar. On a protein basis liver supernatants exhibited a greater capacity to hydrolyze the guanosine nucleotide than the adenosine. The Michaelis constants for cGMP PDE are presented in Table 3. $V_{\max }$ values indicate that liver supernatant has the capacity to hydrolyze cAMP at twice the rate of cGMP at high substrate concentrations. At low substrate concentrations, cGMP would be hydrolyzed at a rate nearly 5 times that of cAMP (see Table 3 ).

\section{DISCUSSION}

cAMP is important in the regulation of the intracellular metabolism of a wide variety of hormonally responsive tissues. It is involved in the mobilization of reserves of carbon and energy when the circulating basic fuel, glucose, becomes limiting $(9,27)$. Thus, cAMP has a stimulatory effect on the gluconeogenic process through activation of glycogenolysis (34), lipolysis (5), the conversion of the amino acids to their keto derivatives in mammals (23), as well as the activation of the liver enzymes required for gluco- 
Table 3. Michaelis constants: Liver cyclic nucleotide phosphodiesterases

\begin{tabular}{|c|c|c|c|c|c|c|c|c|}
\hline \multirow[b]{3}{*}{$\begin{array}{l}\text { Supernatant } \\
\text { fraction }\end{array}$} & \multicolumn{4}{|c|}{ cAMP PDE } & \multicolumn{4}{|c|}{ cGMP PDE } \\
\hline & \multicolumn{2}{|c|}{ High $\mathrm{K}_{\mathrm{m}}$} & \multicolumn{2}{|c|}{ Low $\mathbf{K}_{\mathbf{m}}$} & \multicolumn{2}{|c|}{ High $\mathbf{K}_{\mathbf{m}}$} & \multicolumn{2}{|c|}{ Low $\mathrm{K}_{\mathrm{m}}$} \\
\hline & $\mathrm{K}_{\mathrm{m}}(\mathrm{M})$ & $\begin{array}{l}\mathrm{V}_{\max }(\mathrm{nmol} / \mathrm{mg} \\
\text { protein } / 4 \mathrm{~min})\end{array}$ & $\begin{array}{l}\mathbf{K}_{\mathrm{m}} \\
(\mathrm{M})\end{array}$ & $\begin{array}{l}\mathrm{V}_{\max }(\mathrm{pmol} / \mathrm{mg} \\
\text { protein } / 4 \mathrm{~min})\end{array}$ & $\begin{array}{l}K_{m} \\
(M) \\
\end{array}$ & $\begin{array}{l}\mathrm{V}_{\max }(\mathrm{nmol} / \mathrm{mg} \\
\text { protein } / 4 \mathrm{~min})\end{array}$ & $\begin{array}{l}K_{m} \\
(M)\end{array}$ & $\begin{array}{l}\mathrm{V}_{\max }(\mathrm{pmol} / \mathrm{mg} \\
\text { protein } / 4 \mathrm{~min})\end{array}$ \\
\hline \multicolumn{9}{|l|}{ Control } \\
\hline Mean & $3.60 \times 10^{-41}$ & 30.5 & $4.03 \times 10^{-6}$ & 149.3 & $2.57 \times 10^{-4}$ & 18.4 & $8.28 \times 10^{-6}$ & 730 \\
\hline SD & \pm 1.73 & \pm 27.0 & \pm 1.80 & \pm 106.7 & \pm 0.27 & \pm 6.1 & \pm 5.74 & \pm 540 \\
\hline$n$ & 8 & 8 & 9 & 9 & 4 & 4 & 4 & 4 \\
\hline \multicolumn{9}{|l|}{ Reye's } \\
\hline Mean & $11.36 \times 10^{-41}$ & 42.1 & $3.51 \times 10^{-6}$ & 151.5 & $4.21 \times 10^{-4}$ & 18.1 & $6.68 \times 10^{-6}$ & 1020 \\
\hline SD & \pm 7.73 & \pm 32.8 & \pm 1.96 & \pm 88.7 & \pm 5.39 & \pm 10.2 & \pm 2.38 & \pm 790 \\
\hline$n$ & 6 & 6 & 6 & 6 & 4 & 4 & 4 & 4 \\
\hline
\end{tabular}

${ }^{1} t_{12}+2.7838 ; P<0.025>0.010$.

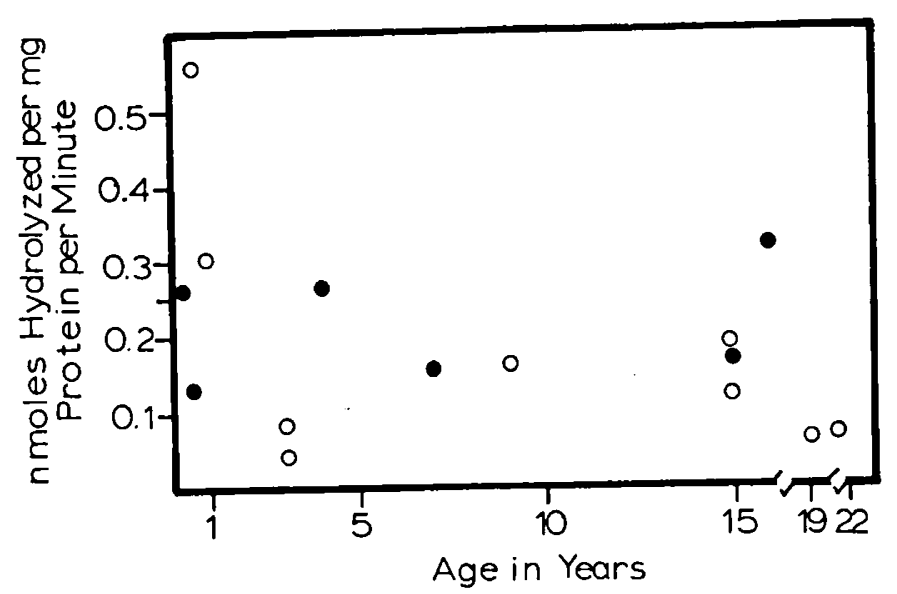

Fig. 5. Effect of age on the specific activity of human liver cAMP phosphodiesterase (low $K_{m}$ enzyme). $\bullet$ : Reye's subjects; $\bigcirc$ : control subjects. cAMP concentration $10 \mu \mathrm{M}$ in reaction mixture containing $40 \mathrm{mM}$ Tris- $\mathrm{HCl}, \mathrm{pH} 7.4 ; \mathrm{Mn}^{++} 2 \mathrm{mM}$; protein $50-100 \mu \mathrm{g}$; total volume $100 \mu \mathrm{l}$, $34-36^{\circ}$.

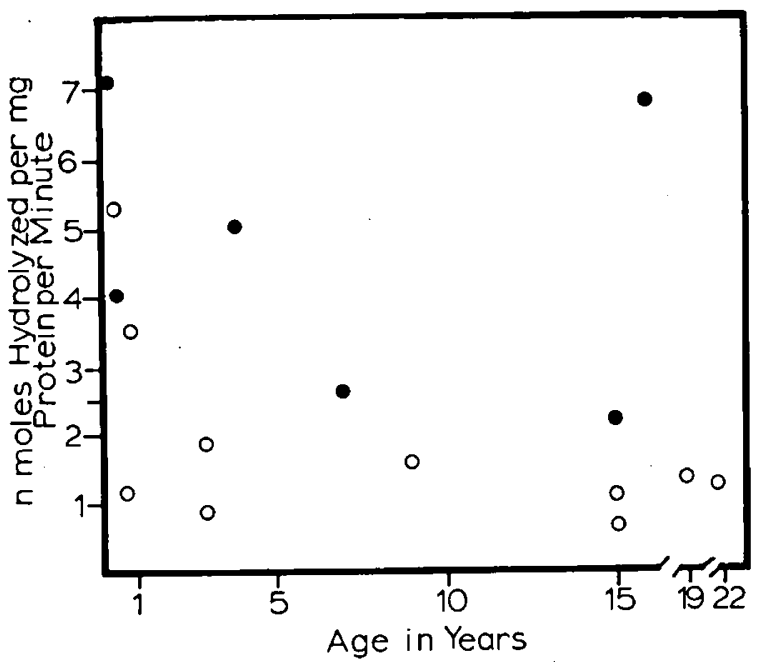

Fig. 6. Effect of age on the specific activity of human liver cAMP phosphodiesterase (high $\mathrm{K}_{\mathrm{m}}$ enzyme). @: Reye's subjects; $\mathrm{O}$ : control subjects. cAMP concentration, $500 \mu \mathrm{M}$ in reaction mixture containing Tris$\mathrm{HCl} 40 \mathrm{mM}, \mathrm{Mn}^{++} 2 \mathrm{mM}$, protein 50-100 $\mu \mathrm{g}$, total volume $100 \mu \mathrm{l}, 34-36^{\circ}$.

neogenesis, in response to hormones which interact with specific receptors on target cells. Many of these effects are opposed by insulin. Insulin levels have been reported as low (11) and high (14) in Reye's syndrome. Glucagon levels are slightly elevated
(14) and cortisol is increased (14). Similar hormone elevations are found under a variety of stress or traumatic situations, which, however, do not result in the metabolic profile observed in Reye's syndrome $(18,19,25)$.

The metabolic features of Reye's syndrome when viewed in the context of the prevailing prandial status of most patients suggests at least two patterns of responsiveness to fasting. Early reports of this disorder indicated that hypoglycemia was a prominent finding (28). Extensions of studies indicate that the blood sugar may be normal $(13,30)$, elevated $(13,14)$, or low $(28,30)$. Hypoglycemia is more likely to occur in infants than in older children (30). In addition, a number of glucose substrates and other fuels are elevated in Reye's syndrome and their elevation does not correlate with the degree of the hypoglycemia. Lactate and pyruvate (14, 30 ), amino acids, especially alanine $(17,30)$, glycerol $(14,16)$, and free fatty acids (3) are found in increased amounts in blood.

Since most of these metabolites can be converted to the universal currency of metabolism, glucose, their accumulation in blood in the presence of hypoglycemia is indicative of a block in the enzymatic pathway in the liver responsible for the conversion of these precursors to glucose. This possibility was suggested by Glasgow et al. (12). The accumulation of these metabolites in the presence of normal or increased levels of glucose in blood, on the other hand, indicates that gluconeogenesis is accelerated, both with respect to the mobilization of substrates from peripheral stores as well as to the conversion of these precursors via the enzymatic processes of the liver. Assuming that the process of mobilization of glucose precursors from adipose tissue and muscle is under complex feedback regulation, elevation of these components when glucose concentrations are normal or increased is indicative of impairment of this highly regulated process $(7,9,10$, 36).

Robinson et al. (29) recently reported that while the activities of pyruvate dehydrogenase and pyruvate carboxylase, which are mitochondrially located, are low in Reye's liver compared to controls, the activities of three key enzymes of gluconeogenesis are normal. Phosphoenolpyruvate carboxykinase, located in both the cytoplasm as well as the mitochondria, and the two wholly cytoplasmically located enzymes, fructose-1,6-diphosphatase and glucose-6-phosphatase, are within normal limits. Thus, precursors such as glycerol and fructose might still enter the pathway of gluconeogenesis despite inhibition or reduction of pyruvate carboxylase activity (which would limit the entry of pyruvate towards glucose production). Entry of precursors via these routes or limitation of the reduction of pyruvate carboxylase activity must account for patients with normal or increased blood glucose levels.

The phosphodiesterases are the only enzymatic means for degrading the cyclic nucleotides. Aberrations of their activities and/or kinetic constants are likely to be reflected by enhancement or inhibition of hormonal effects. Our findings of differences both in the specific activity and $K_{m}$ of the low affinity cAMP PDE of liver raise the possibility that an altered state of responsiveness to 


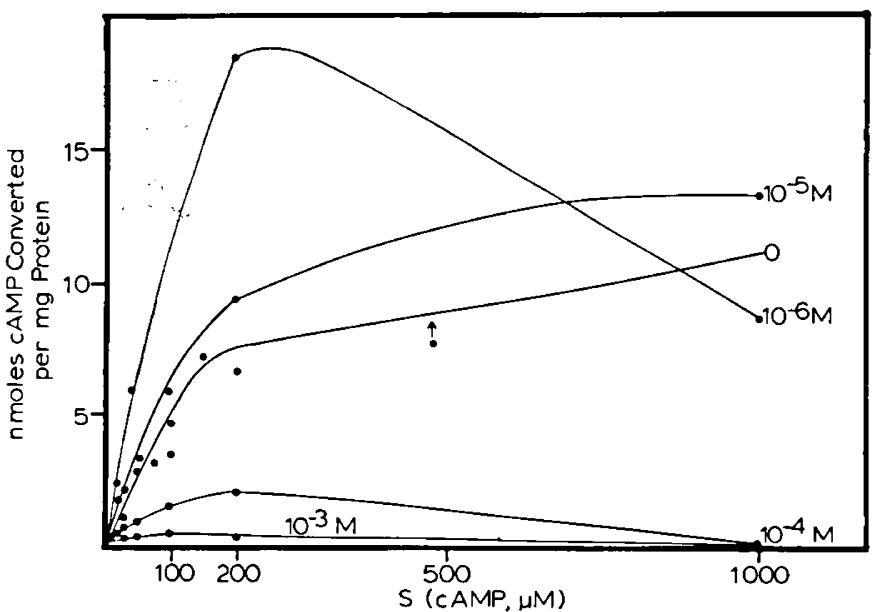

Fig. 7. Effect of cGMP on cAMP PDE activity of the homogenized human liver. $O$ : cAMP PDE activity at varying concentrations in the absence of added cGMP. cAMP PDE activity in the presence of varying concentrations of added cGMP identified by molar concentrations of cGMP from $10^{-6}-10^{-3} \mathrm{M}$.

Table 4. Effects of cGMP on Michaelis constants derived for liver CAMP PDE

\begin{tabular}{|c|c|c|c|c|c|}
\hline & \multicolumn{5}{|c|}{ Final concentration of added cGMP (M) } \\
\hline & 0 & $10^{-6}$ & $10^{-5}$ & $10^{-4}$ & $10^{-3}$ \\
\hline \multicolumn{6}{|l|}{ Control } \\
\hline $\mathrm{K}_{\mathrm{m}_{1}}\left(\times 10^{-4} \mathrm{M}\right)$ & 4 & 1.2 & 1.03 & 2.54 & 3.61 \\
\hline $\begin{array}{l}V_{\max } \\
\quad(\mathrm{nmol} / \mathrm{mg} / \mathrm{min})\end{array}$ & 3.1 & 11.53 & 7.04 & 13.1 & 12.8 \\
\hline $\mathrm{K}_{\mathrm{m}_{2}}\left(\times 10^{-6} \mathrm{M}\right)$ & 3.57 & 8.7 & 10.3 & 5.99 & 5.68 \\
\hline $\begin{array}{l}\mathrm{V}_{\max 2} \\
\quad(\mathrm{pmol} / \mathrm{mg} / \mathrm{min})\end{array}$ & 45 & 1260 & 926 & 461 & 338 \\
\hline \multicolumn{6}{|l|}{ Reye's syndrome } \\
\hline $\mathrm{K}_{\mathrm{m}_{1}}\left(\times 10^{-4} \mathrm{M}\right)$ & 20 & 1.3 & 0.16 & 0.23 & 9.4 \\
\hline $\begin{array}{l}V_{\max 1} \\
\quad(\mathrm{nmol} / \mathrm{mg} / \mathrm{min})\end{array}$ & 12.5 & 13.3 & 0.69 & 10.5 & 20.1 \\
\hline $\mathrm{K}_{\mathrm{m}_{2}}\left(\times 10^{-6} \mathrm{M}\right)$ & 1.39 & 9.0 & 10.9 & 10.3 & 3.13 \\
\hline $\begin{array}{l}\mathrm{V}_{\max 2} \\
\quad(\mathrm{pmol} / \mathrm{mg} / \mathrm{min})\end{array}$ & 13.7 & 1560 & 518 & 746 & 150 \\
\hline
\end{tabular}

${ }^{1} K_{1}$ and $V_{\max _{1}}=$ derived constants for the high $K_{m}$, low affinity cAMP PDE. $K_{m_{2}}$ and $V_{\max 2}=$ derived constants for the low $K_{m}$, high affinity CAMP PDE.

hormonal stimulation might be present in patients who suffer from this disease. The kinetic difference between the two groups (higher $\mathrm{K}_{\mathrm{m}}$ for the low affinity cAMP PDE in Reye's samples) indicates that the intracellular concentrations of cAMP must reach higher levels in the liver of Reye's syndrome subjects before this enzyme can function at maximum velocity.

The high affinity (low $\mathrm{K}_{\mathrm{m}}$ ) enzyme is believed to be of importance in maintaining basal tissue concentrations of the cyclic nucleotides. Since the high affinity forms of PDE for both cAMP and cGMP are similar between control and Reye's samples, it might be expected that tissue concentrations of the cyclic nucleotides under basal conditions are probably similar, assuming rates of synthesis are comparable. However, after stimulation with such hormones as glucagon or epinephrine, intracellular concentrations of cAMP would be expected to be higher in Reye's hepatic cells as compared to control cells, again, assuming rates of synthesis of cAMP are comparable in Reye's as compared to control cells. Adenylate cyclase activity of liver has been reported to be normal in Reye's syndrome (16).

The observed increase in specific activity in Reye's samples may be compensatory to high intracellular concentrations of cAMP since the enzyme, PDE, is readily inducible by substrate (24). The fact that only the high $\mathrm{K}_{\mathrm{m}}$ activity was increased despite the presence of at least three other forms of PDE activity suggests that Reye's subjects may be exposed to increased hormonal stimulation beyond that encountered by non-Reye's syndrome subjects who die of a variety of other conditions. Furthermore, the selective increase of only one of four possible forms of PDE activity conforms to the accepted view that the various forms of PDE are under separate genetic regulation (31).

Our observations are in accord with the high plasma cAMP content and exaggerated persistence of cAMP effects reflected by increased lipolysis and gluconeogenesis as seen in many patients with normal or increased plasma concentrations of glucose. They raise the distinct possibility that hormone responsiveness may be abnormal in this condition and that a premorbid phenotype may be characteristic of children who, at least, succumb to Reye's syndrome.

\section{REFERENCES AND NOTES}

1. Amer, M. S., and Kreighbaum, W. E.: Cyclic nucleotide phosphodiesterases: properties, activators, inhibitors: Structural-activity relationships and possible role in drug development. J. Pharmaceut. Sci., 64: 1 (1975).

2. Beavo, J. A., Hardman, J. G., and Sutherland, E. W.: Stimulation of adenosine 3',5'-monophosphate hydrolysis by guanosine $3^{\prime}, 5^{\prime}$-monophosphate. J. Biol. Chem., 246: 3841 (1971).

3. Brown, R. E., and Madge, G. E.: Fatty acids and metabolic disturbances in Reye's syndrome. Arch. Pathol., 94: 475 (1972).

4. Brown, R. E., Schiller, H. M., Madge, G. E., and Still, J. S.: Reye's syndrome: Ultrastructural features and observations on pathogenesis. South. Med. J., 63: $1230(1970)$.

5. Burns, T. W., Langley, P. E., and Robison, G. A.: Studies on the role of cAMP in human lipolysis. In: P. Greengard, R. Paoletti, and G. A. Robison: Advances in Cyclic Nucleotide Research, Vol. 1, p. 63 (Raven Press, New York, 1972).

6. Burton, K.: Determination of DNA concentrations with diphenylamine. In: L. Grossman and K. Moldave: Methods in Enzymology, Vol. XII, Part B, p. 163 (Academic Press, New York, 1968).

7. Cahill, G. F., Jr., Herrara, M. G., Morgan, A. P., Soldner, J. S., Steinke, J., Levy, P. L., Reichard, G. A., and Kipnis, D. M.: Hormone fuel interrelationships during fasting. J. Clin. Invest., 45: 1751 (1966).

8. Conway, A., and Koshland, D. E., Jr.: Negative cooperativity in enzyme action: The binding of diphosphopyridine nucleotide to glyceraldehyde 3-phosphate dehydrogenase. Biochemistry, 7: 4011 (1968).

9. Exton, J. H., Corbin, J. G., and Harper, S. C.: Control of gluconeogenesis in liver. J. Biol. Chem., 247: 4996 (1972).

10. Felig, P., Pozefsky, T., Marliss, E., and Cahill, G. F., Jr.: Alanine: Key role in gluconeogenesis. Science, 167: 1003 (1970).

11. Glasgow, A. M., Cotton, R. B., and Dhiensiri, K.: Reye's syndrome. I. Blood ammonia and consideration of the nonhistologic diagnosis. Amer. J. Dis. Child., 124: 827 (1972)

12. Glasgow, A. M., Cotton, R. B., and Dhiensiri, K.: Reye's syndrome. II. The hypoglycemia. Amer. J. Dis. Child., 125: 809 (1973).

13. Haller, J. S.: Clinical experience with Reye's syndrome. In: J. D. Pollack: Reye's Syndrome, p. 3 (Grune \& Stratton, New York, 1974).

14. Haymond, M. W., Karl, I. E., DeVivo, D.C C., and Keating, J. P.: Sequential metabolic observations in Reye's syndrome. In: J. D. Pollack: Reye's Syndrome, p. 215 (Grune \& Stratton, New York, 1974)

15. Hilty, M. D., Romshe, C. A., and Delamater, P. V.: Reye's syndrome and hyperaminoacidemia. J. Pediat., 84: 362 (1974).

16. Kang, E. S., Chiang, M. H., Kang, A. H., and Ellsworth, D. L.: Evidence of a transient disturbance of cyclic $3^{\prime}, 5^{\prime}$-adenosine monophosphate metabolism in adipose tissue in Reye's syndrome. In: J. D. Pollack: Reye's Syndrome, p. 261 (Grune \& Stratton, New York, 1974).

17. Kang, E. S., and Gerald, P. S.: Hyperammonemia and Reye's syndrome. New Engl. J. Med., 286: 1216 (1972)

18. Lau, T. S., Tauberfligel, W., Levene, R., et al.: Pancreatic blood flow and insulin output in severe hemorrhage. J. Trauma, 12: 880 (1972).

19. Levenson, S. M.: Metabolic considerations. In: M. H. Weil and H. Shubin: Diagnosis and Treatment of Shock, p. 71 (Williams \& Wilkins, Baltimore, 1967).

20. Levitzki, A., and Koshland, D. E., Jr.: Negative cooperativity in regulatory enzymes. Proc. Natl. Acad. Sci. U. S. A., 62: 1121 (1969)

21. Londesborough, J. O.: Quantitative estimation of 3',5' cyclic AMP phosphodiesterase using anion-exchange resin in a batch process. Anal. Biochem., 71:623 (1976).

22. Lowry, O. H., Rosebrough, N. J., Farr, A. L., and Randall, R. J.: Protein measurement with the Folin phenol reagent. J. Biol. Chem., 193: 257 (1951).

23. Mallette, L. E., Exton, J. H., and Park, C. R.: Control of gluconeogenesis from amino acids in the perfused rat liver. J. Biol. Chem., 244: 5713 (1969).

24. Manangiello, V., and Vaughn, M.: Prostaglandin $E_{1}$ effects on adenosine $3^{\prime}, 5^{\prime}$. cyclic monophosphate concentration and phosphodiesterase activity in fibroblasts. Proc. Natl. Acad. Sci. U. S. A., 69: 269 (1972).

25. Melby, J. C.: Hormonal Factors, In : M. H. Weil and H. Shubin: Diagnosis and Treatment of Shock, p. 87 (Williams \& Wilkins, Baltimore, 1967). 
26. Menahan, L. A., Hepp, K. D., and Wieland, O.: Liver $3^{\prime}: 5^{\prime}$-nucleotide phosphodiesterase and its activity in rat livers perfused with insulin. Eur. J. Biochem., 8: 435 (1969).

27. Muller, W. A., Faloona, G. R., and Unger, R. H.: The effect of alanine on glucagon secretion. J. Clin. Invest., 50: 2215 (1971).

28. Reye, R. D. K., Morgan, G., and Baral, J.: Encephalopathy and fatty degeneration of the viscera-a disease entity in childhood. Lancet, ii: 749 (1963).

29. Robinson, B. H., Gall, D. G., and Cutz, E.: Deficient activity of hepatic pyruvate dehydrogenase and pyruvate carboxylase in Reye's syndrome. Pediat. Res., 11: 279 (1977)

30. Romshe, C. A.: Laboratory diagnosis of Reye's syndrome. In: J. D. Pollack: Reye's Syndrome, p. 15 (Grune \& Stratton, New York, 1974).

31. Russell, T. R., and Pastan, I. H.: Cyclic adenosine 3',5'-monophosphate and cyclic guanosine 3',5'-monophosphate phosphodiesterase activities are under separate genetic control. J. Biol. Chem., 249: 7764 (1974).

32. Russell, T. R., Terasaki, W. L., and Appleman, M. M.: Separate phosphodiesterases for the hydrolysis of cyclic adenosine $3^{\prime}, 5^{\prime}$-monophosphate and cyclic guanosine 3',5'-monophosphate in rat liver. J. Biol. Chem., 248: 1334 (1973).

Copyright @ 1978 International Pediatric Research Foundation, Inc. $0031-3998 / 78 / 1207-0761 \$ 02.00 / 0$
33. Smith, I.: In: Chromatographic and Electrophoretic Techniques, vol. 1 (Interscience, New York, 1960).

34. Sutherland, E. W.: Glycogenolysis. In: G. A. Robison, R. W. Butcher, and E. W. Sutherland: Cyclic AMP, p. 5 (Academic Press, New York, 1971).

35. Thompson, W. J., and Appleman, M. M.: Multiple cyclic nucleotide phosphodiesterase activities from rat brain. Biochemistry, 10: 311 (1971).

36. Ui, M., Claus, T. H., Exton, J. H., and Park, C. R.: Studies on the mechanism of action of glucagon on gluconeogenesis. J. Biol. Chem., 248: 5344 (1973).

37. I wish to thank Drs. Solomon S. Solomon and Seymour Sabesin for their helpful comments, Dr. John Griffith for his encouragement, Dr. J. T. Jabbour for patient referrals, and Mr. Daniel Ellsworth for technical assistance.

38. This research was supported by Grant HD-09469 from the NIH, and by ALSAC (American Lebanese-Syrian Associated Charities).

39. Requests for reprints should be addressed to: Dr. Ellen S. Kang, University of Tennessee Center for the Health Sciences, Room 553 Dobbs, 951 Court Avenue, Memphis, 38163 (USA)

40. Received for publication May 12, 1977.

41. Accepted for publication September 21, 1977. 